UDC 811.111'373.43'42:070

DOI https://doi.org/10.32838/2710-4656/2021.1-2/35

Semen H. Ya.

Yuriy Fedkovych Chernivtsi National University

\title{
LEXICAL INNOVATION IN JOURNALISM
}

The article regards the issue of lexical innovations in the sphere of journalism. The analysis and explanations of certain words will help to better retain the material of news programs in learning English. From lexicological sources 117 lexical units were selected. Though linguists systematically monitor language situation, there always exists the necessity of further detailed explanation and observation of the lexis as new phenomena acquire new nominations, and words that are long used in the language may acquire new meanings.

In the lexicographic sources that served as the basis for investigation all words are given either in alphabetic order or thematic grouping. The main task from the start was to isolate words and word combinations from the rest of the units that were included into the sources. The descriptive method helped to show the semantic and word forming structure of the vocabulary. Innovations concern: 1) the names of the specialists working in mass-media, 2) the naming of devices and activities of journalists, 3) results of this process of activity, 4) evaluation of the newspresentation, the policy of the papers and methods of readers attracting. As to the ways of word formation there is a marked predominance of blending over the examples of conversion or abbreviation. Some lexical units being not new acquire new meaning. Reporters often use euphemisms, the source of information due to some reasons is not directly named. Some words come from proper names, others were coined by journalists and either were forgotten or widely used and found their way into the dictionaries. Words may be both mono- and polysemantic. Their meanings and functioning are explained and illustrated by examples taken from the reliable sources. The further investigations will include the observing of the innovations in the sphere of journalism, as new notions, new events, new theories will always bring new words.

Key words: mass-media, innovations, lexis, coinage, blending, derivation.

The problem under discussion. Journalism, like all spheres of people's activity, is going through a hard process of transformations which involved all genres of this valuable profession. Radio, television and newspapers in their traditional forms gradually give way to new innovative technologies which are speedily developing in recent times. And yet, still having probably a lessened in number audience, both readers and listeners, giving the professional approach in doing their main job of presenting real firsthand information to the wide public, demonstrating ability to answer the challenges of the day traditional ways of journalists' activity are interesting for linguists from all points of view, including the language of it. The given paper will tackle the problem of vocabulary and its innovations in the sphere of British and American English journalism. The topicality of the investigation lies in the fact that the knowledge of the vocabulary innovations helps to better understand the spoken and written English of the news presentation. The novelty of the analysis is presupposed by the material of the investigation which is collected from sources, both British and American, the authors of which tried and did their utmost in gathering the samples of the changes and innovations in different spheres of human activity, journalism including. Lots of endevours have been made already to bring these words and word combinations closer to the public and yet they need further presentation and explanation as ever changing world of ours constantly provides us with new unexpected forms.

The analysis of the recent research and publications. The existing sources of information that can be used nowadays include the glossaries and commentaries, reference-books and dictionaries $[1 ; 2 ; 3 ; 4]$. At the same time all words and word combinations are given according to different principles: thematic, alphabetic, they may include theoretical parts, present the material of real talk, but combine words and references alike under the same title. The main difficulty is to find the words and expressions that belong to the sphere under discussion in order to properly analyze them from the linguistic point of view.

The number of new words in J. Ayto's dictionary (1989) is 1032, lexical units that belong to the sphere of journalism is 52 . Z. Trofimova's dictionary of new words and meanings (2006) include 1034 entries reflecting innovations in English, the number of words 
from the sphere of journalism is 47. Another source for the selection was the dictionary of J. Crotty "How to talk American" (1997). 18 words of the massmedia sphere were added to the selection.

As Z. Trofimova argues, "neological boom" was the result not only of scientific and technical revolution, public relations development, but also the innovations in the sphere of mass-media communication. Reading of press by foreigners becomes rather difficult as new words and word combinations present stumbling blocks for text understanding. The author used a dozen of sources to find new words and illustrate them by vivid examples, among them being William Safire's book "Safire's Political Dictionary". He was the well-knownAmerican writer, journalist, politologist and lexicologist, regularly published the column "Language" in "International Herald Tribune" where he presented new words and meanings [2, c. 3].

The aim of the article. The present paper aims at the analysis of lexical innovations in the sphere of journalism. For achieving them a set of procedures were fulfilled to show the peculiarities of journalism innovations and a number of methods were used. The descriptive method helped to analyze the selected words and word combinations, component analysis proved valuable to regard the semantic structure or the vocabulary. Word building classification was helpful in the defining the predominant kind of word formation in the units. Calculations gave the possibility to state the number of example in the dictionaries, define the major and minor types of word formation of innovations.

Presentation of the material. Judging by the obtained selection innovations in journalism may be grouped as follows:

1) the names of the specialists working in massmedia;

2) names of devices and activities of journalists;

3 ) products, results of this activity;

4) evaluation of the newspresentation process, the policy of the papers and methods of readers attracting.

1) The innovations concern the name of those specialists that work in the given sphere:

E.g. agony aunt noun British a woman who gives counselling on personal problems. This word combination is characteristic of exaggerated hyperbolized emotionality, which makes the journalist closer to the listeners and readers emphasizing family relations. The activity included the help after the crackdown on Army bullying, comprised the whole network of young soldiers. These journalists advised readers or listeners in newspaper columns, on radio, etc.: Fifty new 'agony aunts' will be recruited by the Women's Royal Voluntary Service. Daily Telegraph 28 January 1988. After agony aunt had appeared, the meaning extended and the male variant was added: agony uncle, as in the following example: Since working together on Forum Magazine in the early seventies, their paths have continued to cross and cross. They ...have... become identified as the agony aunt and uncle of our media. Guardian 20 June 1985. Two word combinations can be used together.

The appearance of those working in mass-media is also very important. This was reflected in the coinage mediagenic $=$ media + photogenic. Once there used to be radiogenic (late 1920s), later on telegenic (late 1930s). The synonym is picturesome adjective attractive to look at.

2) Innovations may be observed in the naming of objects, devices or activities in the sphere of massmedia. The following example shows how by means of conversion which is characteristic of English another word of a different part of speech, namely a verb, from the noun box that means a TV set, is formed: to box $=$ to present on television: Royalties from Evelyn Waugh's works in the couple of years after Brideshead was boxed brought about $£ 20,000$ to each of his six children. Guardian 16 Mar 1985.

Another example may be hypermedia noun (in computers) the facility for creating a mixture of text, sounds, video and excessively active and excitable graphics from various packages. A colloquial compound gogglebox - a TV set also belongs to this group. Telescopic word Intelsat stands for International Telecommunications Satellite.

3) The words may denote the products of the journalists' activity.

E.g. bubble noun a new television serial developed from already existing one (typically a soap opera) and incorporating some of its characters: South was the first spin-off [from Brookside] (did you know they call it a bubble now?) Open Air, BBC1, 21Mar 1988. Here metaphorical transference is observed the coinage is of a 'soap bubble'.

One more example may be the word maxiseries noun a television drama presented in a large number of sequential episodes: The $\mathrm{ABC}$ was filming scenes for its 30-part 'maxi-series' "The Last Report" at Bondi last week, and the crew was using special effects to create rain. That's show business. Sydney Morning Herald 13 Apr 1988. In the 1980s the inflated versions of miniseries were very popular with television companies. Nowadays some maxiseries include much more parts, almost hundreds of them. 
4) The innovations include ways of presenting information.

E.g. catastrophize verb American to treat a trivial problem as if it were a major catastrophe: When it comes to dealing with daily obstacles, he says," We have a tendency toward catastrophizing and awfulizing." Newsweek 25 Apr 1988. Recent decades as well as the turn of the century proved to be full of hotbeds, terrorism attacks, hybrid wars and, naturally enough, it is hard to watch it on the screen every day. TV anchors warn the public that images may be distressing, but it is not always helpful.

Innovations in the vocabulary of journalism show the evaluation of the news presentation process, the policy of the papers and their methods used for attracting the readers. Traditionally British newspapers are divided into quality and popular, but blending combined these two words into one reflecting the phenomena that took place in the papers:

E.g. quali-pop noun the use in upmarket 'serious' newspapers of stories and presentational techniques more typical of tabloid newspapers: Not long after that the quali-pop stratego [on The Times] was abandoned. Observer 22 May 1998.

Similar interaction may be observed between the newspaper and television, example being the word combination tabloid television noun television programming designed to appeal to a mass audience by featuring pop music and videos, news and gossip about celebrities, etc. The main impetus for the introduction of the typical subject matter and presentation techniques of tabloid newspapers into television had come from the advertisers.

Words with negative evaluation can be found:

cutting-room journalism noun derogatory the practice of compiling news or background stories by researching old newspaper cuttings and similar sources rather than gathering first-hand information by field work. Observer Magazine from 28 July 1987 cites such an example of "a new Orwellian language introduced into the $\mathrm{BBC}$ by Big Brother Birt whose affairs and newspeak vocabulary included 'Lexpo' ('Long exposition'), 'Bexpo' ('Brief exposition'), 'cutting-room journalism'. The innovations were fast being adopted by ambitious subordinates". Lexpo and Bexpo proved to be for internal use only, but the last expression was included into the dictionary.

Words appear in the language in case of the necessity to nominate some notions or events. Measures taken by some governments are reflected by the lexical unit gazetting noun, Singapore English the placing of an official restriction on the sales or distribution of a newspaper or similar publication: The government has severely restricted the distribution of publications that deemed to be delving into Singapore's domestic politics or presenting a distorted view of the country: "Gazeting, as it's called, is a powerful weapon; Singapore, with its highly educated and prosperous population, is one of Asia's largest media outlets. Newsweek 15 February 1988.

Restrictions of the government is also recorded in the following unit: D. Notice a censored memorandum sent by the English government to mass media and banning to publicize certain information for the reason of national defence. D. stands for defence.

Lots of new words that appeared in journalism are formed by means of blending:

plugumentary $=$ plug + documentary,

squaerial $=$ square + aerial,

sit-tragedy $=$ situational +tragedy,

vidkid $=$ video+kid,

televangelism $=$ television+evangelism

(televangelist),

televangelist $=$ television + evangelist,

telenovela $=$ television + novela,

teledish $=$ television + dish,

telebook $=$ television + book,

telecoms $=$ television + communications,

infomercial $=$ information + commercial,

docufantasy $=$ documentary + fantasy,

drama-com $=$ drama + comedy, comedy-drama, dramedy (Am.).

Affreviations are much less in number RDS - Radio Data System, CPM: cost per thousand circulation, so are examples of conversion: to wok verb to cook using a wok-bowlike traditional Chinese cooking pot - the word used in cooking shows; to stand-first verb to provide (a newspaper article) with an introductory summarizing its content. The word geddit stands for get it? and preposition into is used instead of on, about.

Many old words acquire new meanings:

spreading: speaking as fast as is humanly possible;

textbook: a representative example; book:

a magazine;

art: from sales art - the advertisement (ad);

a lot of words came from ads:

shoot: a photo session for an ad campaign,

hole: ad space available at the last minute; fractional: any ad that is smaller than a full page. The phenomenon is called specialization of words $[1$, p. 66].

Journalists sometimes avoid due to different reasons naming the source of information calling it back channel. Oftentimes reporters tend to use 
euphemisms: redundancy instead of unemployment. The secret tongue of reporters and pundits full of the most often used at a given moment words is called journalese. US News and World Reporter from May 21, 1990 published the article where it is illustrated by examples: "actress model", "one time beauty queen" really mean "bimbo", agreeable means wimpy, well-known - tiresome.

Some words come from the proper names. X.M. McLuhan, the Canadian sociologist argued that mass-media form the character of the society and that mass culture gives the people the access to spiritual value. He struggled with the printed word, but some considered him to be an explorer and experimenter, hense, McLuhanism is a word denoting his theories about the dominating role of mass-media in the society.

Words may be monosemantic:

newsreader noun an announcer reading the breaking news and polysemantic: newsmaker 1) a person who is the center of interest of mass-media, 2) a celebrated personality or an outstanding event.

Affixation also has its influence on the meaning of the words: prefix para - in the word parajournalism gives the sense of some opposition. Parajournalism is new journalism so-called "secret press". It is a special manner in journalism when the author takes everything close to heart, becomes too personally involved in describing the events. A lot of publications appeared opposing themselves to the existing press, the so-called underground press was mounting a serious challenge to established dailies (The American Annual).

Words may come from two different spheres, but combined into one word combination reflect the activity of television:

wholesale politics noun, chiefly American electoral campaigning via the media, especially television, while traditional methods of campaigning such as addressing meetings, rallies, canvassing, touring around is called retail politics.

Terms used in trade being attributes for the noun politics came to be used with transferred meaning in mass-media. An example of blending toytoon noun an animated cartoon for children featuring characters of which models can be bought as toys. It is a deliberate tying in of a television series with toys, toytoon $=$ toy + cartoon. This is also an example of market economy in action. There are words with both positive and negative connotations.

Positive: educational television - this word combination indicates the cognitive programmes having cultural value (without ads), equal time
American means equal number of minutes allocated free on different days, but at the same time to the representatives of different parties or groups. Fireside chat is a warm, unofficial address of a prominent public figure (most often Resident) to the listeners and viewers on the radio and TV. Resident F.D. Roosevelt was the first to give fireside chat and was very effective as a radio speaker.

Negative implications can be traced in the following units: Iran-gate.

Suffix-gate being added to some word gives it extremely negative connotation with the hint of possible scandal. News management stands for news manipulation and censorship of information, presenting it according to the needs of the government. Black Radio broadcasts the radio programs of psychological war to the opponent side presented in the name of the adversary. Flackery as a jargon word means advertisement, publicity (especially of the political figure) comes from flake, also American jargon with the meaning of bright, excentric, extraordinary. A biased covering of events and press backing of one party only are rendered by the word combination one-party press. The prefix over- shows the excess of something and is used in the following coinages: overexposure as an annoying, intolerant advertisement of some political figure by the massmedia, the verb being to overexpose. The desire to see one's name in the press has got another denomination: Potomac fever which stands for the capital of the US as Washington is situated on the Potomac river. The skill of presenting oneself from the most favorable side, the ability of self-promotion in American jargon is called showboating. An advisor, a public opinion-maker, often a representative on the links with the press who tries to interpret the wording and events in the necessary key and direction is known as spin doctor or spinmeister. Some call them the PR generals. Hatchetman noun is a journalist who unscrupulously uses libel, juggling with facts. There is an example of hatchetwoman. Hype is a jargon word for shameless advertising, humbug and any trick for attracting attention.

Some words are hard to be referred to either of the two groups as they are used in the contexts with both positive and negative connotations or are neutral and just have their denotational meaning. Examples may be as follows: The press conference or interview with one journalist which is an official one, the name of the interviewee remains anonymous (often the name of the president) is called backgrounder. A massive wide campaign on TV held in the last days before the election is referred to as TV blitz. 
Information for the press is known as handout: Good reporters profess to ignore "handouts" and dig for themselves; however the informative handout can be helpful and timesaving. A handout is usually directly given by press agents to reporters; a release (press release) may either be handed out or mailed. W. Safire "Safire's Political Dictionary." An influential political observer has got another name pundit. The investigation of public opinion is called trial balloon (American). It is done anonymously by the President or another public figure with the help of mass-media. This is a way to study background, argument, good and bad reaction. The latest news is most often referred to as the latest update. The source of information is called pipeline.

Some words even reflect the combining of both positive and negative connotations: The American journal "The Time" created the word dawk $=$ dove + hawk - a person that is not approving the war, but refuses to actively fight for peace.

Conclusions. Vocabulary of every language constantly develops. The task of the linguists is to observe, analyze, collect and explain the units that appear in the language. Journalism has greatly changed recently. Due to the appearance of new technologies the number of listeners of the radio, TV viewers, readers of the press greatly lessened. But the development of new ways of news presenting, the fulfilment of journalists their main fundamental task - informing and educating the public should be based on longstanding tradition of the best samples in this profession. The assiduous and systematic work at the English language, linguistic analysis of innovations of different kinds should be paid great attention to. The perspective of the research is the gathering and further observation of new linguistic facts in the sphere of journalism.

\section{References:}

1. Зацний Ю. А. Неологізми англійської мови 80-90 років XX століття. Запоріжжя : РА «Тандем-У», 1997. $396 \mathrm{c}$.

2. Трофимова 3. C. Dictionary of New Words and Meanings. Словарь новых слов и значений в английском языке. Москва : АСТ : Восток-Запад, 2006. 320 c.

3. Ayto J. The Longman Register of New Words. Special Edition. London : Longman UK Ltd, 1989. 434 p.

4. Crotty J. How to talk American. A Guide to Our Native Longues. Boston ; New York : Houghton Muffin Company, 1997. $420 \mathrm{p}$.

\section{Семен Г. Я. ЛЕКСИЧНІ ІННОВАЦЇ̈ В ЖУРНАЛІСТИЦІ}

У статті розглядається питання лексичних інновачій у сфері журналістики. Аналіз та пояснення окремих слів допоможе краще засвоювати матеріал новинних програм у вивченні англійської мови. Із лексикологічних джерел було відібрано 117 слів та словосполучень. Хоча лінгвісти систематично моніторять мовну ситуачію, завжди існує необхідність подальшого детального пояснення та спостереження за лексикою, оскільки нові явища отримують нові позначення, а слова, що давно вживаються в мові, можуть отримувати нове значення. У лексикографічних джерелах, що слугували основою для дослідження, слова подаються або в алфавітному порядку, або згруповані тематично. Із самого початку основним завданням було відділити слова та словосполучення від інших одиниць, ще входять у словники. Описовий метод сприяє висвітленню семантики та словотвору виділеної лексики. Інновації стосуються: 1) назв спеціалістів, щзо праџюють у медіа, 2) діяльності журналістів, 3) результатів даної діяльності, 4) основних принципів процесу роботи, подачі новин, залучення читачів. 3 точки зору способів словотвору спостерігається значне переважання злиття над прикладами конверсії чи абревіатури. Деякі лексичні одиничі не є новими, але набувають нових значень. Репортери часто використовують евфемізми, джерело інформаціїчерез певні причини може не вказуватися. Деякі слова утворюються від власних назв, окремі лексичні одиниці були створені самими журналістами. Частина з них вийшла з ужитку, частина - увійшла у словники. Лексичні одиниці можуть бути як моно-, так і полісемантичними. Значення пояснюються та ілюструються прикладами у відповідних словниках. Подальше дослідження включатиме спостереження за інновачіями у сфері журналістики, оскільки нові поняття, нові події, нові теорії завжди будуть створювати нові слова.

Ключові слова: мас-медіа, інновачї̈, лексичні одинииі, новотвори, злиття, дериваџія. 